\title{
Petdeset let Evropskega združenja za izobraževanje odraslih
}

EAEA, vse najboljse za rojstni dan

$V$ novembru je v Larnaki na Cipru zasedala generalna skupščina organizacïje EAEA (European Association for the Education of Adults), $k i$ je letos praznovala petdesetletnico obstoja. Petdeset let! Doba, v kateri je organizacija, ki se je več desetletij innenovala Evropski biro izobraževanja odraslih, prehodila dolgo pot. Vseskozi je nosila pečat osebnosti in strokovnega delovanja svojih članov pa tudi spreminjajočilh se družbenih razmer.

V času po drugi svetovni vojni so mnogi verjeli, da bo mednarodno povezoranje na vrsti področij, in tudi $v$ izobraževanju odraslih, pomagalo popraviti "Prizadeti svet". Prva UNESCO-va svetovna konferenca izobraževanja odraslih je bila leta 1949 v Elsenore. Bila je še precej evropskoameriška konferenca, ki ji je botrovalo prepričanje, da do vojne prihaja v glavah ljudi in da bi bilo s kulturo in izobraževanjem vojne moč preprečiti. Spoznanje, ki bi ga veljalo upoštevati tudi danes.

Leta 1950 je sledil šesttedenski seminar v Mondseeju, ki je bil za mnoge udeležene živa izkušnja mednarodne skupnosti (G. H. L. Schouten, The Mondsee Seminar, its problems and results. $\checkmark$ Conference Report "25 years after Mondsee", St. Wolfgang, 1974, Amersfort, 1974).

Evropski biro zà izobră̌evanje odraslih je ugledal luč tudi zahvaljujoč se prizadevanjem Nizozemca Oscarja Guermonpreza in na podlagi izkušenj nizozemskih ljudskih visokih sol, pa tudi Britanca Edwarda Hutchinsona ... Združba prijateljev, $k i$ so jih vodile skupne vrednote. Guernonprez si je želel, da bi se kulturni centri,

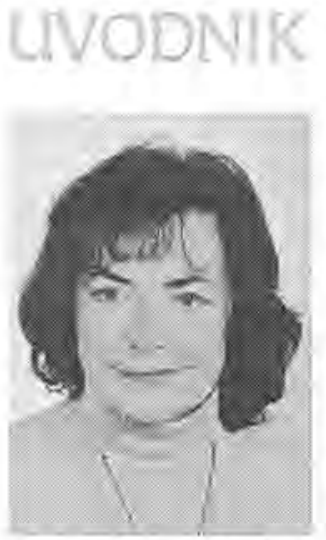

Prof. dr. Ana Krajnc ljudske visoke šole, večerne šole za odrasle in druge tovistne nacionalne mreže povezale med seboj znanstveno in dokumentacijsko. $V$ tem je zaznati idejni zametek Evropskega biroja za izobraževanje odraslih.

Vaporedno s tem so si tudi drugi prizadevali za mednarodno sodelovanje, denimo Evropski center za kulturo v Ženevi, ki so ga ustanovili leta 1950 z namenom, da pripravi Evropejce na Evropsko zvezo. Ob tem je Center imel še pomembnejšo nalogo: ohranjati in razvijati kulturo. Pod vodstvom Denisa de Rougemonta so $v$ Centru pripravljali dejavnosti in kovali zamisli, ki naj bi vodile v Evropsko zvezo kulturnith centrov. De Rougemont je verjel, da Evropa ne bi smela biti zveza močnih držav, konstrukt brez duše in nerazumljiv množicam. Ljudsko izobraževanje (fr: education populaire) naj bi varovalo lokalno in nacionalno raznolikost in posebnosti. Še več, De Rougemont je spodbudil nastanek različnih kulturnih drustev, glasbenih festivalov ipd., zato ni nenavadno, da je leta 1950 posègel tudi na izobraževanje odraslih. Obstoječe mreže izobraževanja odraslih, na primer mrě̌e ljudskih visokilh šol, so kulturo dojemale kot del izobraževanja odraslih. Tako so se različni napori strnili.

Ustanovitelji so si želeli, da bi v Evropskem biroju združili ljudi, ki bi imeli sirši pogled na izobraževanje odraslih in pregled nad sistemi tega izobraževanja v posameznih drăavah. Na stičišču vseh teh in drugih podobnil prizadevanj je od 18. do 23, maja 1953 v Versoixu blizu Ženeve potekal prvi sestanek Evropskega biroja, 
kjer so sodelujoči, skupaj dvajset, v nacionalnih poročilih predstavili dejavnosti organizacij za izobraževanje odraslih in preučili možnosti in oblike sodelovanja. Oscar Guermonprez je postal prvi predsednik Evropskega biroja in je to funkcijo zadržal od leta 1953 do leta 1963.

Leta 1972 je na Kongresu Zveze andragoških društev Jugoslavije v Budvi Evropski biro za izobraževanje odraslih predstavljal takratni predsednik biroja in direktor britanskega Nacionalnega inštituta za izobraževanje odraslih Edward Hutchinson. Tu so se znašli tudi drugi, denimo Kanadčan Robin Kidd, ki je zasnoval Svetovno organizacijo za izobraževanje odraslih (nastala je dvajset let po Evropskem biroju). Prišli so z namenom, da razložijo poslanstvo mednarodnih organizacij. Takrat, v Budvi, so nas Jugoslovane prvič povabili, da sodelujemo v Evropskem biroju. Leta 1974 sem s pomočjo Biroja lahko odšla na enomesečno specializacijo v Oxford, študijskih obiskov pa so bili deležni tudi drugi "kadri" Evropskega biroja. Na ta način oziroma tudi tako se je utrjevalo njegovo poslanstvo.

$V$ čem je bil dosežek Evropskega biroja? Predvsem v pripravi konferenc in seminarjev, študijskih obiskov. Omogočal je formalno in neformalno srečevanje strokovnjakov. Tudi sama sem se jih na povabilo Biroja udeleževala dolga leta kot opazovalka. Leta 1985, ko sem predsedovala Zvezi andragoških društev Jugoslavije, mi je zvezo uspelo priključiti Biroju. Postali smo prva socialistična evropska država članica.

Leta 1991 so udeleženci Skupšcine Evropskega biroja ob vključitvi estonskega andragoškega društva v Biro kolegici Talvi Mariji iz Estonije izročili "svečko za rojstni dan". Stisnilo me je pri srcu, kajti moja prizadevanja za vključitev slovenskega andragoškega društva - kljub mojemu dolgoletnemu predhodnemu sodelovanju v Biroju - niso obrodila sadov. Slovenija še ni bila priznana država in naše vloge ni bilo moč upoštevati. Tolažili so me, da bo boljše naslednje leto 1992.

Evropski biro se je preimenoval v Evropsko društvo za izobraževanje odraslih. Spodbuja izobraževanje in učenje za vse. Cilji izobraževimja, ki ga društvo spodbuja, so osebnostna rast, samouresničenje, dejavno državljanstvo. Pa tudi družbene spremembe, trajnostino okolje, kulturna in medkulturna osveščenost, znanje, spretnosti in razvoj izobraževanja za delo. Svojo vlogo vidi drušstvo predusem v zagovornišstvu politike vseživljenjskega učenja.

Tudi danes, tako kot v preteklosti, stori vse, da so člani dobro obveščeni o dogajanju in da sodelujejo v mnogih izobraževalnih dejannostih. Spodbuja povezovanje članov: da skupaj oblikujejo nove izobraževalne programe, mednarodno raziskujejo, izobražujejo ... in pomagajo, še posebej skupinam na družbenem robu. Tistim torej, ki se srečujejo s tako imenovano "novo revščino" in ki osamljeni, jezni, obupani in diskriminirani čemijo na družbenem robu.

Za prihodnja leta delovanja je društvo izbralo področje dejavnega državljanstva, temeljnih znanj in spretnosti, ki jih potrebujejo stevilni funkcionalno nepismeni, in priznavanje neformalno pridobljenega znanja.

Evropsko društvo za izobraževanje odraslih je botrovalo nastanku evropskega programa Socrates Grundtwig in letos na Cipru podelilo tudi prvo Evropsko nagrado Grundtwig. Prejele so jo partherske organizacije, ki so se posvetile "ucenju evropskih žensk". Učenju za premagovanje brezposelnosti in vključitev $v$ družbo. 